\title{
Pharmacological activity of different solvent extracts of Tribulus terrestris against multi drug resistant Staphylococcus aureus isolated from post-operative wound patients
}

\author{
M.S. Uma Maheshwari, R. Rajendran and S. Vijayalakshmi \\ ${ }^{1}$ Associate Professor, Department of Microbiology, Tiruppur Kumaran College for Women, Tiruppur, India \\ ${ }^{2}$ Associate Professor, Department of Microbiology, PSG College of Arts and Science, Coimbatore, India \\ ${ }^{3}$ Research Scholar, PG and Research Department of Zoology, Division of Microbial Technology, Chikkanna \\ Govt. Arts College, Tirupur, India
}

\begin{abstract}
Despite advances in infection control surgical site infections formerly called surgical wound infections, remain a substantial cause of morbidity and mortality among hospitalized patients. The post-operative surgical site infection is the third most commonly reported nosocomial infections, accounting for a quarter of all such infections. The early stages of invasive infection caused by Staphylococcus aureus, also play major role in this process. In this present study a total of 50 pus samples were collected from patients having postoperative wound infections from the different surgical departments in the PSG Institute of Medical Sciences and Reasearch (PSG IMSR), Coimbatore during Dec 2016 to July 2017. Identification of bacterial isolates was done by standard microbiological techniques. Further, the antimicrobial susceptibilities were done against following antibiotics, Penicillin (10 units), Chloramphenicol (30mcg), Vancomycin (30mcg), Streptomycin (10mcg), Neomycin (30mcg), Ampicillin (10mcg), Amoxicillin (10mcg), Amikacin (10mcg), Gentamycin (10mcg) and Ciprofloxacin (10mcg). Among these strains 100\%, 30\%, 90\%, 50\%, 40\%, 100\%, 50\%, 20\%, 30\% and 60\% were found to be exhibiting a significant degree of resistance to antibiotics tested. Currently, the development of bacterial resistance has necessitated the search for new antibacterial agents to combat the infectious disease using bio-medically active different solvent extract of Tribulus terrestris for antimicrobial activity. In this present study the maximum inhibition was observed in Ethyl acetate, moderate inhibition in Ethanol, minimum inhibition in Acetone, Chloroform, Methanol and no inhibition in aqueous and Petroleum ether. The results confirm that, the plant appears to contain substances that exhibit broad antimicrobial activity against wound pathogens.
\end{abstract}

KEY WORDS: STAPHYLOCOCCUS AUREUS, ANTIBIOTIC RESISTANCE, ANTIMICROBIAL ACTIVITY OF TRIBULUS TERRESTRIS, POSTOPERATIVE WOUND INFECTION

ARTICLE INFORMATION:

"Corresponding Author: maheswariuma938@gmail.com Received $27^{\text {th }}$ Oct, 2017

Accepted after revision $27^{\text {th }}$ Dec, 2017

BBRC Print ISSN: 0974-6455

Online ISSN: 2321-4007 CODEN: USA BBRCBA

. Thomson Reuters ISI ESC and Crossref Indexed Journal

NAAS Journal Score 2017: 4.31 Cosmos IF: 4.006

$\odot$ A Society of Science and Nature Publication, 2017. All rights reserved.

Online Contents Available at: http//www.bbrc.in/

DOI: $10.21786 / \mathrm{bbrc} / 10.4 / 22$ 


\section{INTRODUCTION}

Recurrently, the post operative hospital acquired infections constitutes a major problem in surgical patients contributing to morbidity, mortality and increased resource utilization and health care costs. Patients in whose surgical site infection develop have an increased number of associated complications, the high risk of requiring a stay in ICU have two to three times higher risk of mortality. Their hospital stay is increased by 7 to 12 days and they are five times more likely to require readmission.The post-operative wound infections can be caused by different groups of microorganisms like bacteria, fungi and protozoa. However, different kind of microorganisms can exist in polymicrobial communities, especially in the margins of wounds and in chronic wounds (Percevil and Bowler, 2004, Anaya and Dellinger, 2006 and Jain et al. 2014) .

The risk of invasive burn wound infection is influenced by the extent and depth of the burn injury, various host factors, and the quantity and virulence of the microbial flora colonizing the wound (Church et al. 2006). The common burn wound pathogens are Staphylococcus aureus, Pseudomonas aeruginosa, Escherichia coli and Klebsiella spp., which produce a number of virulence factors that are important in the pathogenesis of invasive infection (Tredget et al. 2004) are frequently associated with post-operative wound infection. One of the major problems worldwide is the increase in antibiotic-resistant strains of bacteria, mainly in hospitals, that poses constrain for their control without considerable resources and expenditure (Ayliffe et al. 2000). It has been well documented that most of the clinical isolates of Staphylococcus aureus are multiple-drug resistant currently used antibiotics. The problem of microbial resistance is increasingly alarming and the outlook for the use of antimicrobial drugs in the future is still uncertain (Nascimento et al. 2000 Naaz 2017).

Due to this treatment of postoperative wound infection with antibiotics is becoming a challenge for the surgeon as multidrug resistance is reported to be high. It is therefore, important to have knowledge regarding the prevalent microorganism in the surgical units and their susceptibility patterns to antibiotics so that proper treatment can be started earlier. It is essential to take appropriate steps to curtail the spread of infection within the unit (Tahir, 1995). One of the measures to combat this increasing rate of resistance is to have continuous investigations into new, safe and effective antimicrobials as alternative agents to substitute with less effective ones. Plants have been traditionally proved to be a rich source of novel drug compounds, as the herbal mixtures have made large contributions to human health and well-being (Ergin and Mutlu, 1999). A wide vari- ety of secondary metabolites, such as tannins, terpenoids, alkaloids, quinones and flavonoids are endowed with antimicrobial properties (Lewis and Ausubel, 2006 Mohammad et al 2015).

Currently, the research is being carried out to investigate ethno-botanical uses of plants prevailing among native people (Sibanda and Okoh, 2007). There are numerous reports evidencing the antibacterial activity of plants against microorganisms (Sundharameshwari and Radhika, 2007). Thus, it is very much necessary to analyze the potential of the plants in combating the antibiotic resistant organisms, (Al Maofari 2013).

Recurrently, the Tribulus terrestris is a strong herbal remedy which is used for various purposes in folk and modern medicine and sport, as well. It has been used as a tonic, aphrodisiac, astringent, analgesic, stomachic, anti-hypertensive, antibacterial, antifungal, skin infection and urinary anti-septic (Al-Bayati and Al-Mola, 2008). T. terrestris has been commonly used as a diuretic as well as treatment for hypertension, hypercholesterolemia and colic pains. (Wang et al., 1990).The leaves of Tribulus terrestris are used traditionally for the treatment of various kinds of wound. T. terrestris is found to be a rich source of calcium (Bourke et al., 1992). Extract from $T$. terrestris has immune stimulatory and antimicrobial effect (Sengul et al., 2009, Al Maofari 2013) against pathogens. Recently Naz et al., (2017) stated that the leaf extracts of plants with a history of traditional use should be tested using modern methods for activities against multidrug resistant human pathogens, with the aim of discovering potential new drugs. So, hence the present study has made an attempt to point out the different solvent extraction of Tribulus terrestris against multidrug resistant Staphylococcus aureus isolated from wound of post-operative patients.

\section{MATERIALS AND METHODS}

A total of 50 pus samples was collected from patients aseptically with a sterile cotton swab suffering from post operative wound infection at the PSG Institute of Medical Sciences and Reasearch (PSG IMSR), Coimbatore for the period of Dec 2016 - July 2017. For collection, the wound sample was washed thoroughly with normal saline and it was placed in the ice box. After reaching to the laboratory of PG and Research Department of Microbiology, PSG College of Arts and Science, Coimbatore. Finally the samples were incubated at $37^{\circ} \mathrm{C}$ for 24 hours in isolation of wound pathogens.

All the strains isolated from wound samples were serially diluted, plated onto Mannitol Salt Agar, it was incubated at $37^{\circ} \mathrm{C}$ for 48 hours. The colonies with characteristic growth were subjected to routine biochemical test according to the Bergey's manual of systematic bacteriology. 


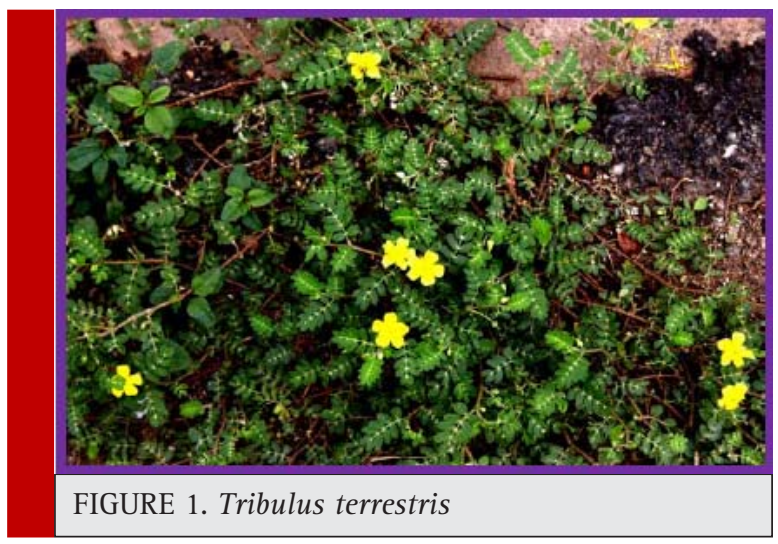

The standard Kirby Bauer disk diffusion method was used to determine the antimicrobial profile of wound isolates against 10 antimicrobial agents such as Penicillin (10 units), Chloramphenicol (30mcg), Vancomycin (30mcg), Streptomycin (10mcg), Neomycin (30mcg), Ampicillin (10mcg), Amoxycillin (10mcg), Amikacin (10mcg), Gentamycin (10mcg) and Ciprofloxacin (10mcg). The diameters of the inhibition zone were measured using a ruler under a colony counter apparatus. The results were expressed as sensitive (S), marginally susceptible (I), and resistant (R).

The plants of Tribulus terrestris were collected from the dry lands of Coimbatore and Tirupur regions and identified. The identification was authenticated by the Botanical Survey of India ,Tamilnadu Agricultural University Campus (TNAU),Coimbatore. The plant extracts were prepared as per standard procedures. The leaf of $T$. Terrestris plant (Fig. 1) were washed with sterile distilled water to remove dirt, dried under shade and were ground to powder using household electric blender. The $20 \mathrm{~g}$ of dry powdered Terrestris was weighed and transferred to a conical flask containing $100 \mathrm{ml}$ of $80 \%$ of Ethanol, methanol, Chloroform, acetone, Ethyl acetate and Petroleum ether (Fig. 2) respectively and allowed to soak at ambient temperature for 72 hours. The extract was than filtered using Whatman no 1 filter paper and the filtrates were concentrated in vaccum at $40^{\circ} \mathrm{C}$ using a rotary evaporator. Residues of the extracts made into suspensions using sterile distilled water and sterile dimethyl sulphoxide at a concentration of $500 \mathrm{mg} / \mathrm{ml}$ of Tribulus extracts respectively.

The leaf of the purified Tribulus extract was tested for antibacterial activity by standard agar well diffusion method against pathogenic bacteria S.aureus. The pure culture of bacterial pathogen was sub cultured on nutrient agar. $20 \mathrm{ml}$ of nutrient agar were poured into petriplates. The well of $6 \mathrm{~mm}$ diameter were made on nutrient agar using gel puncture $100 \mu \mathrm{l}$ of fresh over night grown culture of the respective bacteria were spread on nutrient agar medium containing petriplates. The culture was
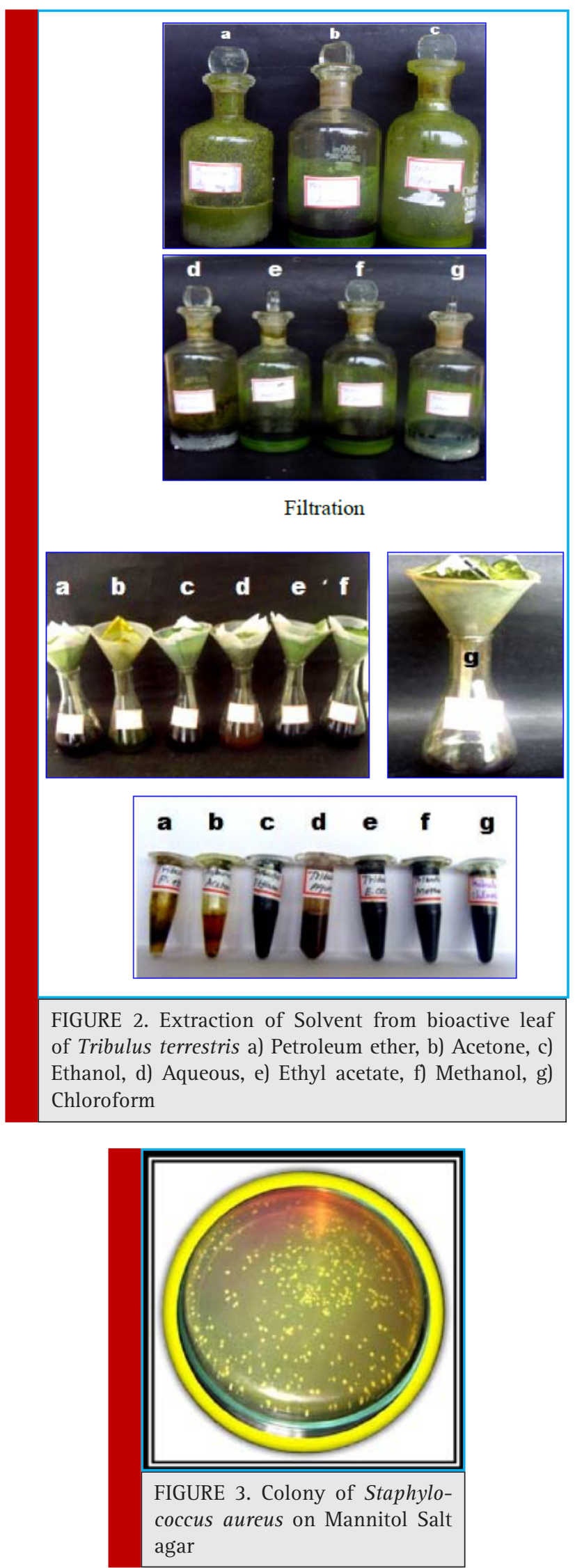
Table 1. MIC of different strains of Petroleum ether extract of Tribulus terrestris by broth dilution method

\begin{tabular}{|c|c|c|c|c|c|c|c|c|c|c|c|c|}
\hline \multirow[t]{2}{*}{$\begin{array}{l}\text { Test } \\
\text { microorganism }\end{array}$} & \multicolumn{12}{|c|}{$\begin{array}{l}\text { Plant Extract (Petroleum ether) } \\
\text { Concentration }(500 \mathrm{mg} / \mathrm{ml})\end{array}$} \\
\hline & $\begin{array}{l}100 \\
(\mu l)\end{array}$ & $\begin{array}{l}50 \\
(\mu l)\end{array}$ & $\begin{array}{l}25 \\
(\mu l)\end{array}$ & $\begin{array}{c}12.5 \\
(\mu l)\end{array}$ & $\begin{array}{c}6.25 \\
(\mu 1)\end{array}$ & $\begin{array}{c}3.12 \\
(\mu \mathrm{l})\end{array}$ & $\begin{array}{l}1.56 \\
(\mu l)\end{array}$ & $\begin{array}{c}0.78 \\
(\mu l)\end{array}$ & $\begin{array}{c}0.39 \\
(\mu l)\end{array}$ & $\begin{array}{c}0.19 \\
(\mu l)\end{array}$ & $\begin{array}{c}0.09 \\
(\mu l)\end{array}$ & $\begin{array}{c}0.04 \\
(\mu \mathrm{l})\end{array}$ \\
\hline MTUM02 & - & - & + & + & + & + & + & + & + & + & + & + \\
\hline MTUM03 & - & - & + & + & + & + & + & + & + & + & + & + \\
\hline MTUM05 & - & - & + & + & + & + & + & + & + & + & + & + \\
\hline MTUM06 & - & - & + & + & + & + & + & + & + & + & + & + \\
\hline MTUM07 & - & - & + & + & + & + & + & + & + & + & + & + \\
\hline MTUM09 & - & - & + & + & + & + & + & + & + & + & + & + \\
\hline
\end{tabular}

swabbed uniformly using a sterile cotton swab and then $50 \mu l$ of the plant extract solution was loaded into the well. After incubation at $37^{\circ} \mathrm{C}$ for 24 hours the different zone of inhibition was measured.

Minimum inhibition concentration was made by the lowest cost of the extract of $T$. Terrestris leaves where it can show the bactericidal and bacteriostatic effect. The test was performed in 96 well micro titer plates. Microtiter plate wells from each column in row 1 were marked and $100 \mu \mathrm{l}(500 \mathrm{mg} / \mathrm{ml})$ of stock (aqueous and solvent extract) was added. $50 \mu \mathrm{l}$ of sterile distilled water was added to rows 2-12. Two fold serial dilutions were performed by transferring $50 \mu \mathrm{l}$ of solution from row 1 to 2, using a multichannel pipette. This was repeated down the row 2 to 12 . $40 \mu \mathrm{l}$ of double strength nutrient broth and $10 \mu \mathrm{l}$ of bacterial culture was added to all the wells in a separate column, so the final concentration of the inoculum in all the wells. Finally, to prevent dehydration, the plates were covered with a plastic cover and then incubated at $37^{\circ} \mathrm{C}$ for overnight. The bacterial growth was determined after adding of $40 \mu \mathrm{l}$ of 2, 3, 5 Tri Phenyl Tetrazolium Chloride Red $(0.02 \mathrm{mg} / \mathrm{ml})$. The Minimum inhibitory concentration (MIC) of the isolates was taken as the lowest concentration of the antibiotic of which the bacteria tested did not show visible growth (Table: 1).

\section{RESULTS AND DISCUSSION}

Totally 50 clinical wound samples, 10 positive Staphylococcus aureus were isolated from different wound sites of patients admitted in surgical ward in the PSG Institute of Medical Sciences and Research (PSG IMSR) (Fig. 2), Coimbatore. All the wound samples were tested on Mannitol Salt Agar (MSA) for the isolation of S.aureus. On MSA, S.aureus colonies were appeared yellow colour which is containing mannitol to detect mannitol fermentation. In the routine microbiological laboratory, prompt identification of the $S$. aureus was done by grams staining, catalase, oxidase, coagulase, IMViC, nitrate reduction test, triple sugar iron agar test. After performing, all these tests was confirmed as S.aureus.

All the 10 S.aureus isolates were tested invitro to determine their antibiotic susceptibility patterns by antibiotic disc diffusion method and the following antibiotic discs were used for this assay are Penicillin (10 units), Chloramphenicol (30mcg), Vancomycin (30mcg), Streptomycin (10mcg), Neomycin (30mcg), Ampicillin (10mcg), Amoxycillin (10mcg), Amikacin (10mcg), Gentamycin (10mcg) and Ciprofloxacin (10mcg).. Totally 10 antibiotic discs were used to identify vancomycin resistant Staphylococcus aureus. All the isolates were shown multiple antibiotic resistances to the antibiotic tested none of the isolates showed 100\% resistant to antibiotics tested. The maximum resistant pattern percentage $(80 \%)$ was recorded in strain no MBUM02, MBUM06 and MBUM07 followed by minimum resistant pattern percentage (30\%) was recorded in strain no MBUM01 and MBUM08.

Among 10 strains, 2 isolates were shown 30\% resistant against all the antibiotics tested with strain No. MBUM01 and MBUM08 both were showed equally with the following antibiogram: VAN- AMP-P followed by the strain no. MBUM10, MTUM04 were showed 40\% with antibiogram of STR-CHL-AMP-P, STR-CHL-AMPCIP. Two strains MBUM03 and MTUM05 were showed 50\% against the antibiotics tested with antibiogram of VAN-AMX-NEO-AMP-P followed by one strain no. MBUM09 was exhibit 70\% resistant to antibiotics tested: VAN-AMX-AMP-P-GEN-AK-CIP, these antibiogram was recorded in the isolate. Finally, three strains MBUM02, MBUM06 and MBUM07 was showed the highest resistant percentage of $80 \%$ with the antibio- 


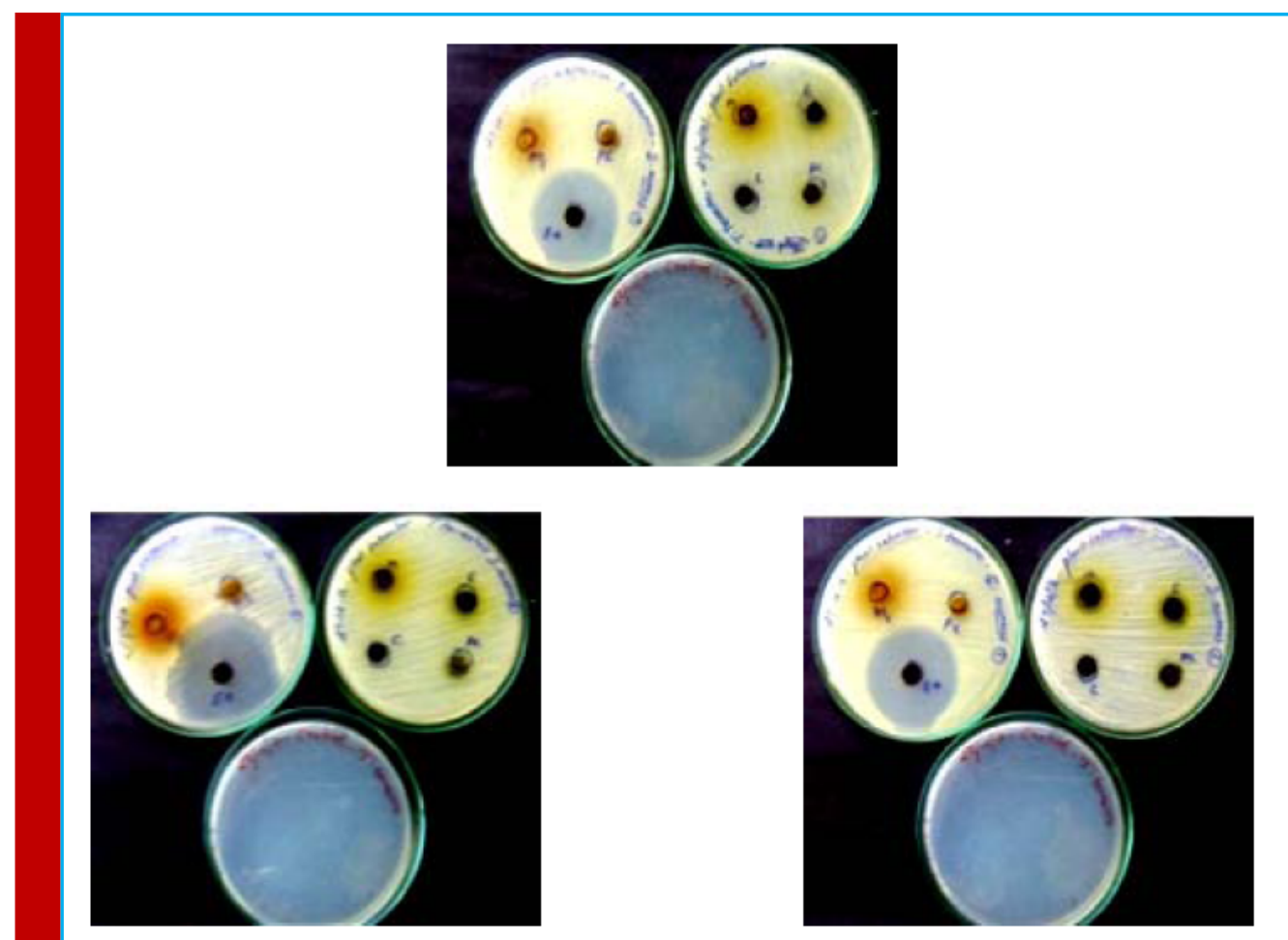

FIGURE 4. Antimicrobial activity of different solvent extract of Tribulus terrestris against Staphylococcus aureus shows that the maximum inhibition was seen in Ethyl acetate extract of Tribulus terrestris. The moderate inhibition was seen in Ethanol extract of Tribulus terrestris. The minimum inhibition was seen in the Acetone, Chloroform extract Tribulus terrestris. No inhibition of Tribulus terrestris was seen in the Aqueous and Petroleum ether extract of Tribulus terrestris. a) P.E-Petroleum ether, (b) AQ-Aqueous, (c) E.A-Ethyl acetate, (d) M-Methanol, (e) E-Ethanol , (f) CHL-Chloroform, (g) AC-Acetone.

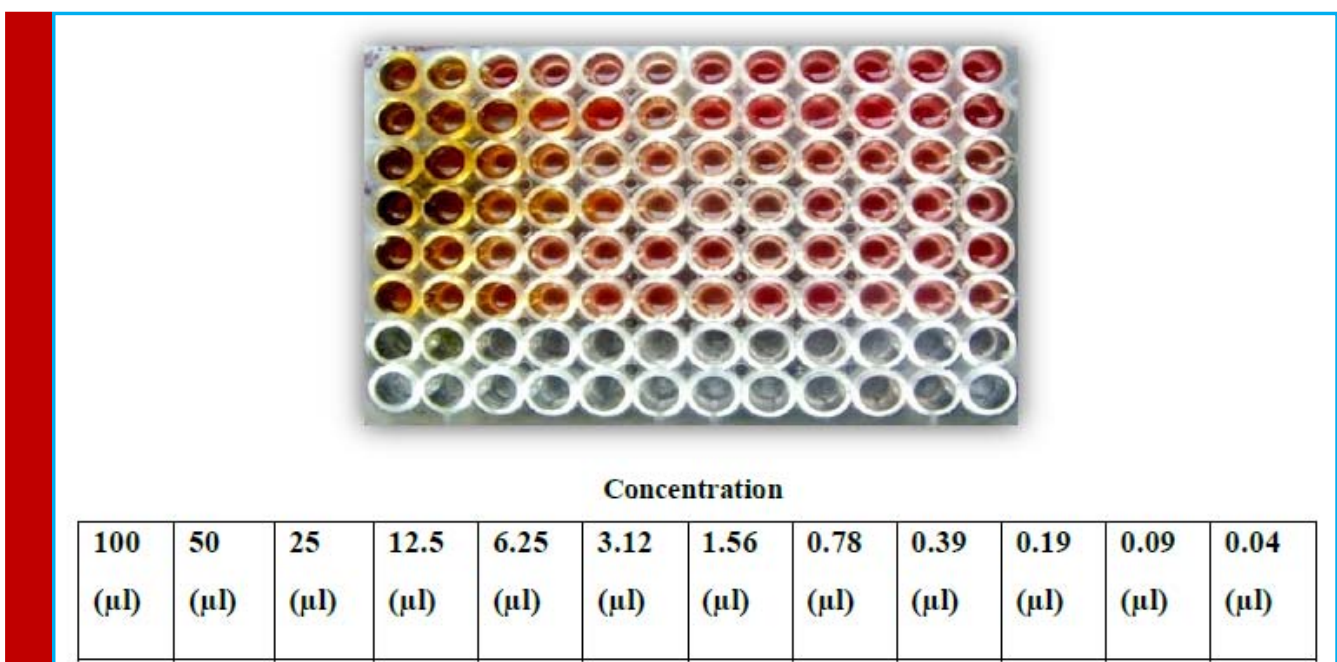

The maximum inhibitory concentration was recorded in $25 \mu \mathrm{l}-0.04 \mu \mathrm{l}$ con.of petroleum ether extract of Tribulus terrestris followed by minimum was recorded in 50 and $100 \mu$ con.of extract

FIGURE 5. MIC of different strains of Petroleum ether extracts of Tribulus terrestris by broth dilution method 


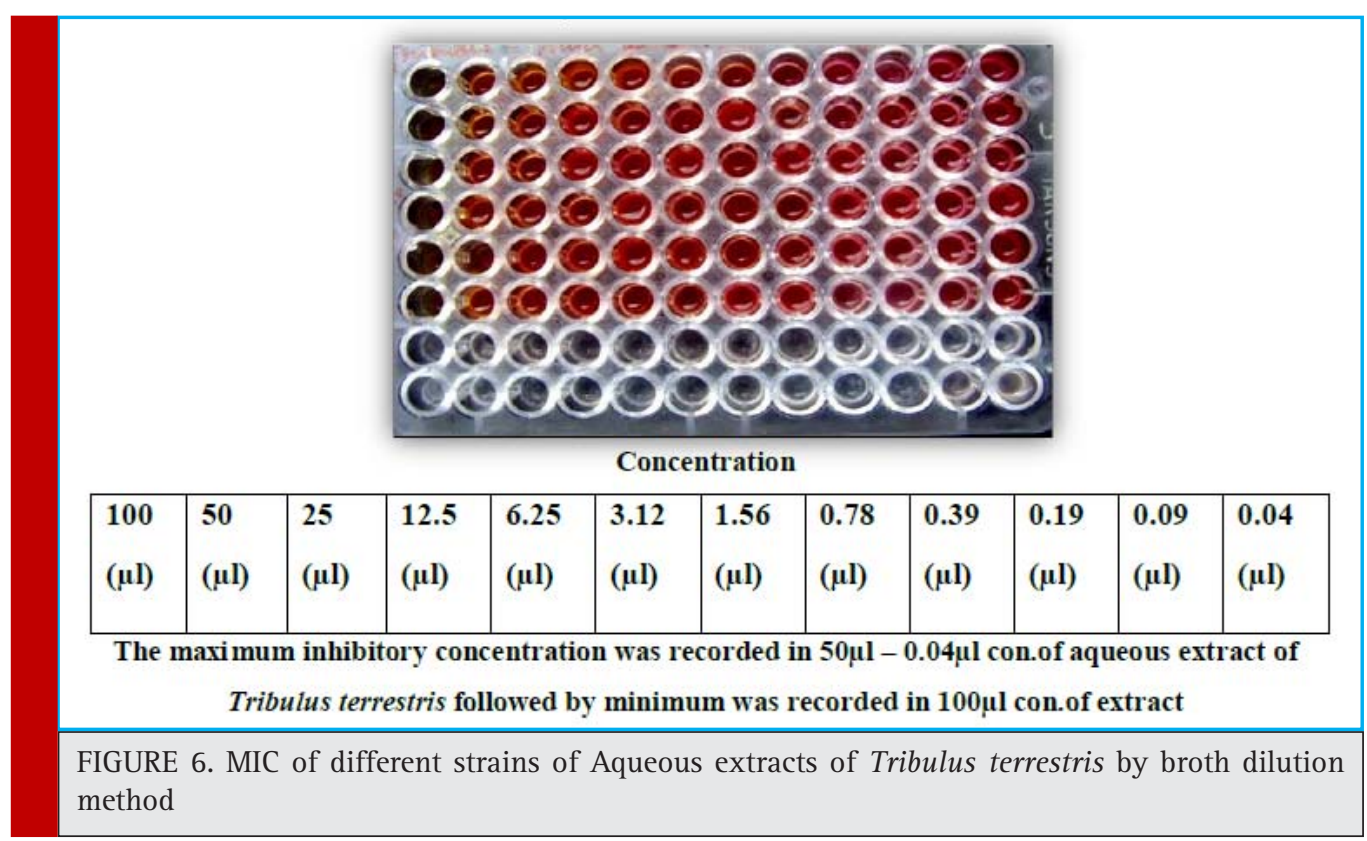

gram of STR-VAN-AMX-NEO-CHL-AMP-P-CIP; STRVAN-AMX-NEO-AMP-P-GEN-CIP and STR-VAN-CHLAMP-P-GEN-AK-CIP.

Totally 10 antibiotics were used to know the resistant pattern, among, 10 antibiogram were recorded. Ten antibiotics were showing more than $20 \%$ resistant to the isolates. All isolates (100\%) were resistant of Ampicilin and Penicillin, while Vancomycin showed resistance (90\%), Ciprofloxacin (60\%), Streptomycin and Amoxyillin (50\%), Neomycin (40\%), Chlorompenical and Gen- tamycin (30\%) followed by Amikacin (20\%). All the Staphylococcus aureus isolates showed multiple antibiotic resistances. Such that one isolate resisted four, six and seven types of antibiotics, two isolates resisted 3 types of antibiotics, three isolates resisted eight antibiotics. The multiple antibiotic resistances (MAR) index was calculated according to the MAR index formula. The Maximum MAR index 0.8 was shown by MTUM08, MTUM06, MTUM07 and minimum MAR index 0.3 was shown by MBUM01 and MBUM08

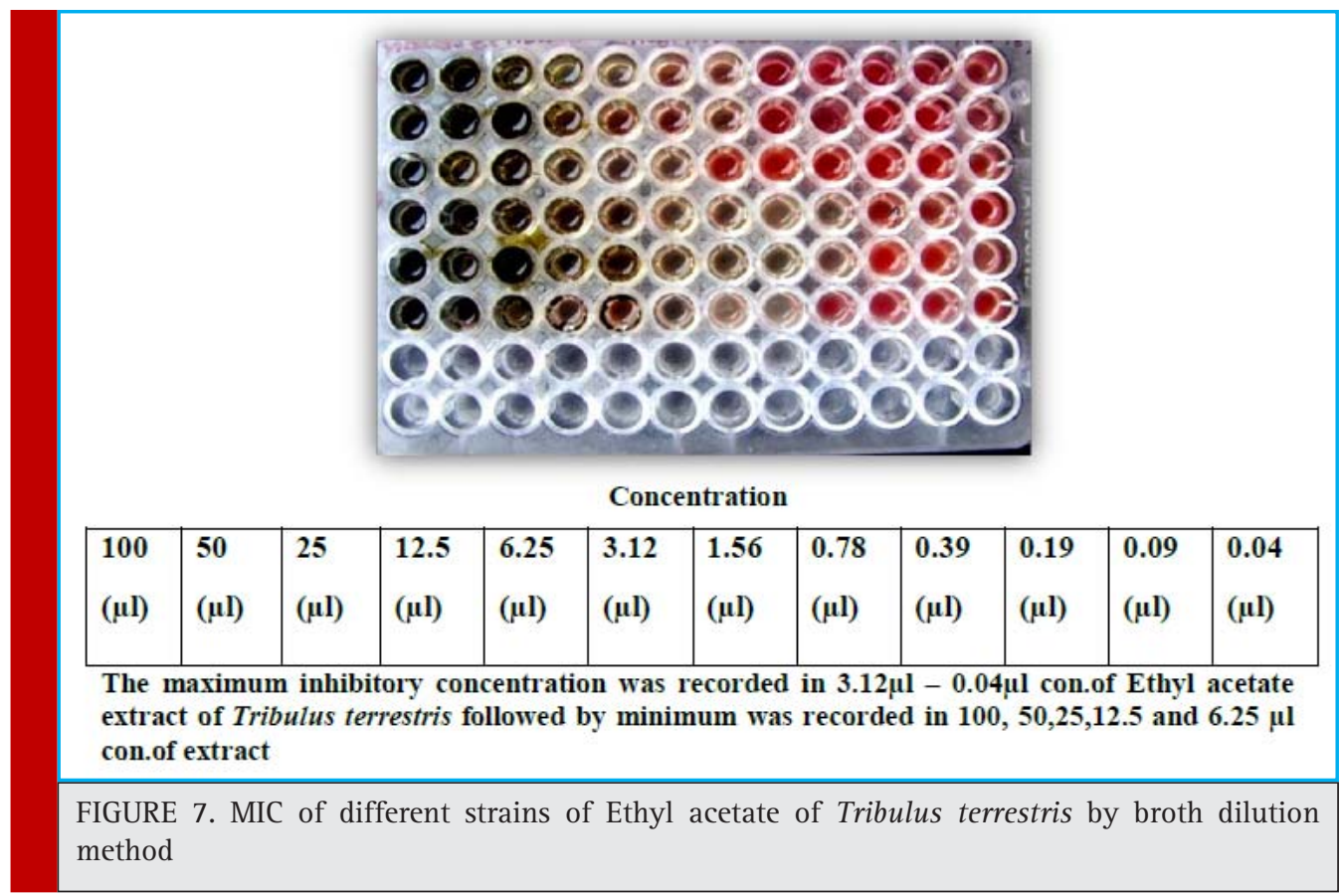




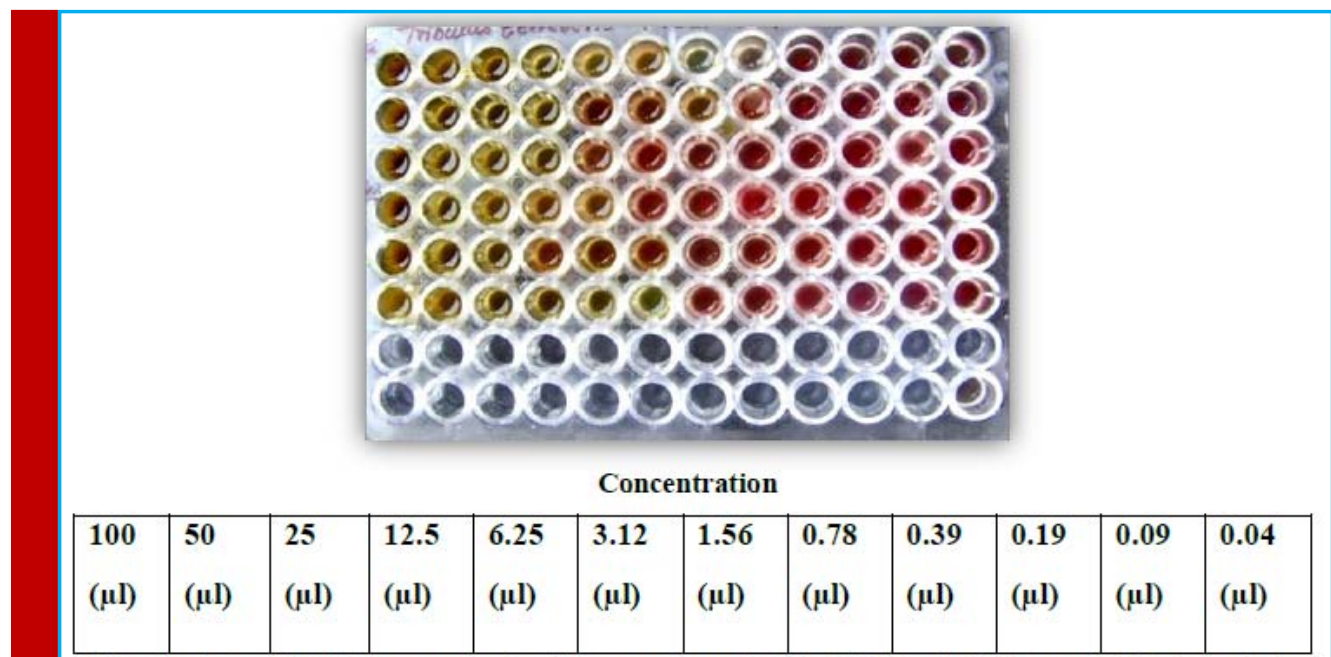

The maximum inhibitory concentration was recorded in $3.12 \mu \mathrm{l}-0.04 \mu \mathrm{l}$ con.of Ethyl acetate extract of Tribulus terrestris followed by minimum was recorded in 100, 50,25,12.5 and $6.25 \mu \mathrm{l}$ con.of extract

FIGURE 8. MIC of different strains of Methanol of Tribulus terrestris by broth dilution method

Based upon the MDR (Multiple Drug Resistance), seven strains of Staphylococcus aureus were selected for further studies. Finally, the strains were tested with purified leaf extract of various solvents using Tribulus for antimicrobial activity and showed maximum inhibition in Ethyl acetate, moderate inhibition in Ethanol, minimum inhibition was recorded in Acetone, Chloroform, Methanol and no inhibition observed in Aqueous and Petroleum ether solvents. Minimum inhibitory concentrations were performed to determine the minimum concentration of antibiotics, which is effective on the wound pathogens were also recorded and compared to currently used antibiotics, the plant extract of Tribulus terrestris shows effective results (Fig. 5 to fig. 11).

Post-operative wound infection still remains one of the most important causes of morbidity and is one of the most common nosocomial infection (Suljagic et al., 2010) in surgically treated patients. In the present study, an attempt has been made to know the predominant pathogen Staphylococcus aureus is the major respon-

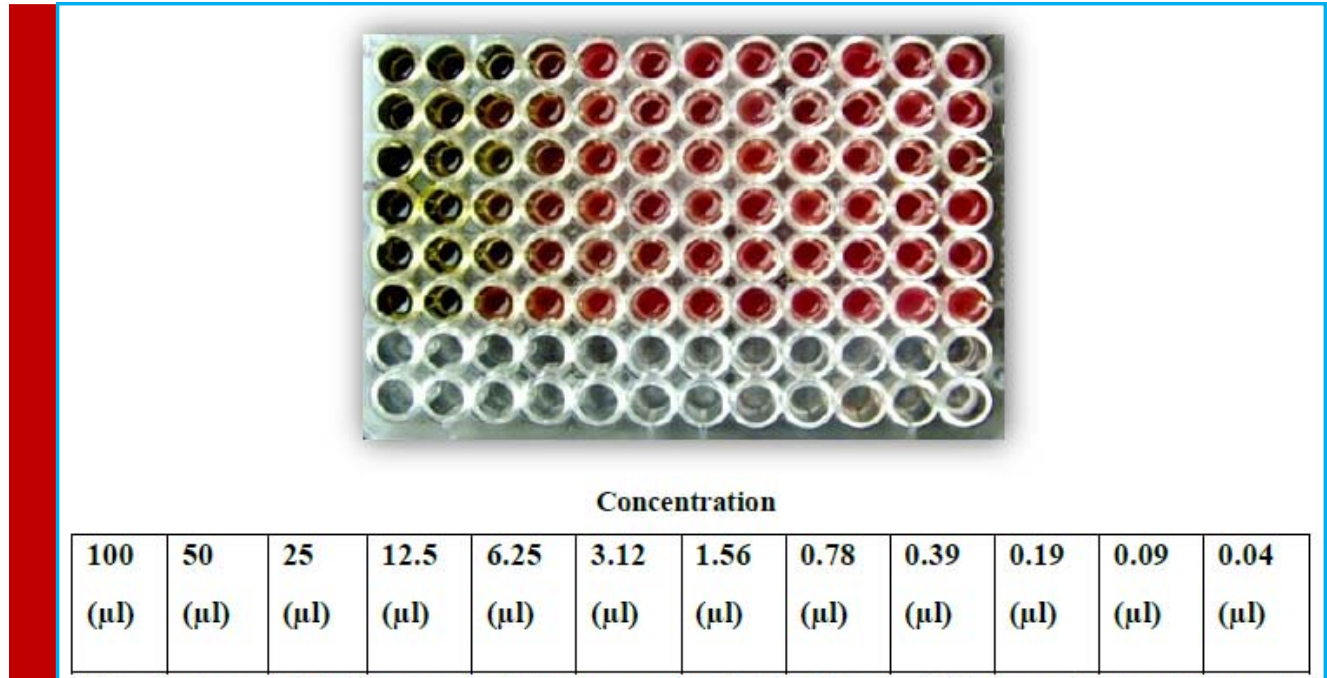

The maximum inhibitory concentration was recorded in $12.5 \mu \mathrm{l}-0.04 \mu \mathrm{l}$ con.of Ethanol extract of Tribulus terrestris followed by minimum was recorded in 100,50 and $25 \mu \mathrm{l}$ con.of extract

FIGURE 9. MIC of different strains of Ethanol of Tribulus terrestris by broth dilution method 


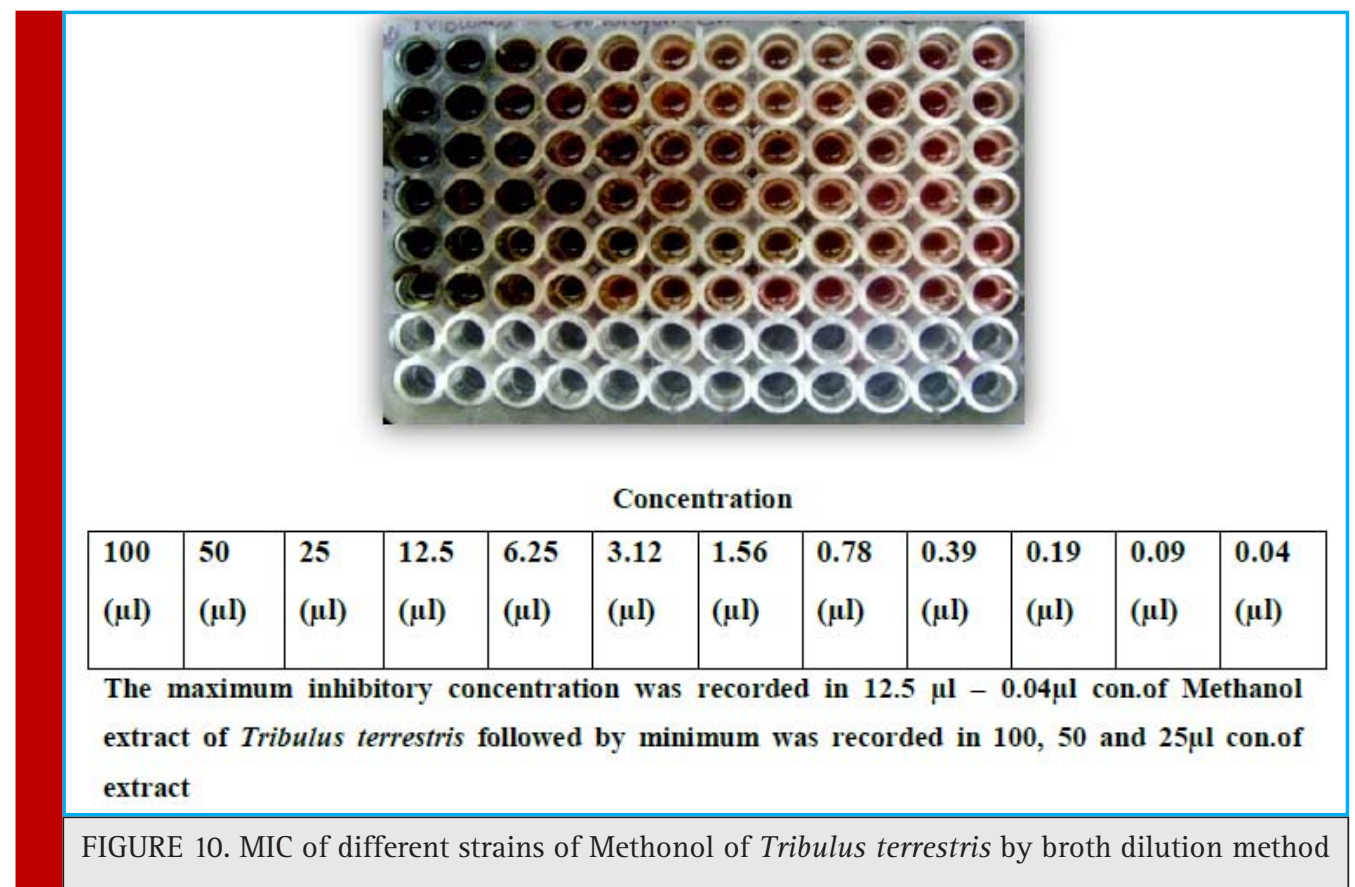

sible for surgical site infections and their antibacterial susceptibility pattern. The rate of surgical site infection varies greatly worldwide and from hospital to hospital. The rate of SSI varies from $2.5 \%$ to $41.9 \%$ as per different studies. The incidence of SSI in the present study is $2.69 \%$ even though high, is in agreement with the various studies (Reichman and Greenberg, 2009).
Wound infections inflict clinical and societal consequences on the patients, but its bacteriological characteristic varies with different factors. Therefore, effective treatment and management of wound infections in hospital and community setting will require detailed epidemiological knowledge of the infecting bacterial pathogens and their antibiogram peculiar to the environment.

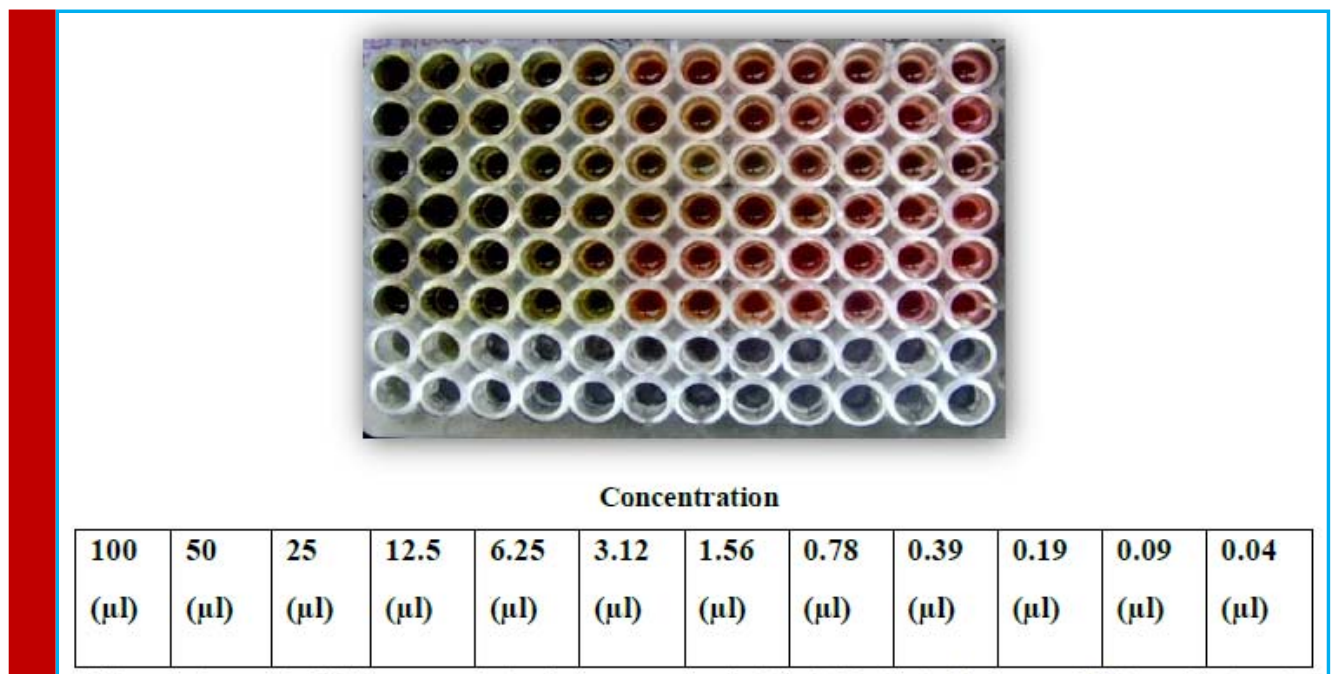

The maximum inhibitory concentration was recorded in $3.12 \mu \mathrm{l}-0.04 \mu \mathrm{l}$ con.of Ethanol extract of Tribulus terrestris followed by minimum was recorded in $100,50,25,12.5$ and $6.25 \mu 1$ con.of extract

FIGURE 11. MIC of different strains of Chloroform of Tribulus terrestris by broth dilution method 


\begin{tabular}{|c|c|c|c|c|c|c|c|c|c|c|c|c|}
\hline \multirow[t]{2}{*}{$\begin{array}{l}\text { Test } \\
\text { microorganism }\end{array}$} & \multicolumn{12}{|c|}{$\begin{array}{c}\text { Plant Extract (Aqueous) } \\
\text { Concentration (500mg/ml) }\end{array}$} \\
\hline & $\begin{array}{l}100 \\
(\mu l)\end{array}$ & $\begin{array}{l}50 \\
(\mu l)\end{array}$ & $\begin{array}{l}25 \\
(\mu l)\end{array}$ & $\begin{array}{l}12.5 \\
(\mu l)\end{array}$ & $\begin{array}{l}6.25 \\
(\mu l)\end{array}$ & $\begin{array}{l}3.12 \\
(\mu l)\end{array}$ & $\begin{array}{l}1.56 \\
(\mu l)\end{array}$ & $\begin{array}{l}0.78 \\
(\mu \mathrm{l})\end{array}$ & $\begin{array}{l}0.39 \\
(\mu l)\end{array}$ & $\begin{array}{l}0.19 \\
(\mu l)\end{array}$ & $\begin{array}{l}0.09 \\
(\mu l)\end{array}$ & $\begin{array}{l}0.04 \\
(\mu l)\end{array}$ \\
\hline MTUM02 & - & + & + & + & + & + & + & + & + & + & + & + \\
\hline MTUM03 & - & + & + & + & + & + & + & + & + & + & + & + \\
\hline MTUM05 & - & + & + & + & + & + & + & + & + & + & + & + \\
\hline MTUM06 & - & + & + & + & + & + & + & + & + & + & + & + \\
\hline MTUM07 & - & + & + & + & + & + & + & + & + & + & + & + \\
\hline MTUM09 & - & + & + & + & + & + & + & + & + & + & + & + \\
\hline
\end{tabular}

Table 3. MIC of different strains of Ethyl acetate extract of Tribulus terrestris by broth dilution method

\begin{tabular}{l|l|l|l|l|l|l|l|l|l|l|l|l|}
\hline $\begin{array}{l}\text { Test } \\
\text { microorganism }\end{array}$ & \multicolumn{10}{|c|}{$\begin{array}{l}\text { Plant Extract (Ethyl acetate) } \\
\text { Concentration }(500 \mathrm{mg} / \mathrm{ml})\end{array}$} \\
\hline & $\begin{array}{l}100 \\
(\mu \mathrm{l})\end{array}$ & $\begin{array}{l}50 \\
(\mu \mathrm{I})\end{array}$ & $\begin{array}{l}25 \\
(\mu \mathrm{I})\end{array}$ & $\begin{array}{l}12.5 \\
(\mu \mathrm{I})\end{array}$ & $\begin{array}{l}6.25 \\
(\mu \mathrm{I})\end{array}$ & $\begin{array}{l}3.12 \\
(\mu \mathrm{I})\end{array}$ & $\begin{array}{l}1.56 \\
(\mu \mathrm{I})\end{array}$ & $\begin{array}{l}0.78 \\
(\mu \mathrm{I})\end{array}$ & $\begin{array}{l}0.39 \\
(\mu \mathrm{I})\end{array}$ & $\begin{array}{l}0.19 \\
(\mu \mathrm{I})\end{array}$ & $\begin{array}{l}0.09 \\
(\mu \mathrm{I})\end{array}$ & $\begin{array}{l}0.04 \\
(\mu \mathrm{I})\end{array}$ \\
\hline MTUM02 & - & - & - & - & - & - & - & + & + & + & + & + \\
\hline MTUM03 & - & - & - & - & - & - & - & + & + & + & + & + \\
\hline MTUM05 & - & - & - & - & - & - & + & + & + & + & + & + \\
\hline MTUM06 & - & - & - & - & - & - & - & - & - & + & + & + \\
\hline MTUM07 & - & - & - & - & - & - & - & - & - & + & + & + \\
\hline
\end{tabular}

Based on this information, the author (Bularafa Mohammed Yasidi et al., 2015) examined the prevalence and antibiogram of bacterial pathogens isolated from wound infection cases seen at the hospital over the study period. A total of 392 wound swabs/ and pus of different types of wound infections from different anatomical sites and associated clinical conditions were analyzed by standard bacteriological methods. Of the 392 clinical specimens analyzed, 301(76.8\%) yielded the majority of pathogens were recovered from septic wound infections. Overall, 7 different bacterial pathogens were identified.

The authors state that among different kind of microorganisms the major pathogen Staphylococcus aureus was isolated and used for antimicrobial testing. The

\begin{tabular}{|c|c|c|c|c|c|c|c|c|c|c|c|c|}
\hline \multirow[t]{2}{*}{$\begin{array}{l}\text { Test } \\
\text { microorganism }\end{array}$} & \multicolumn{12}{|c|}{$\begin{array}{l}\text { Plant Extract (Methanol) } \\
\text { Concentration }(500 \mathrm{mg} / \mathrm{ml})\end{array}$} \\
\hline & $\begin{array}{l}100 \\
(\mu l)\end{array}$ & $\begin{array}{l}50 \\
(\mu \mathrm{I})\end{array}$ & $\begin{array}{l}25 \\
(\mu \mathrm{I})\end{array}$ & $\begin{array}{l}12.5 \\
(\mu \mathrm{I})\end{array}$ & $\begin{array}{l}6.25 \\
(\mu \mathrm{I})\end{array}$ & $\begin{array}{l}3.12 \\
(\mu \mathrm{I})\end{array}$ & $\begin{array}{l}1.56 \\
(\mu \mathrm{I})\end{array}$ & $\begin{array}{l}0.78 \\
(\mu \mathrm{I})\end{array}$ & $\begin{array}{l}0.39 \\
(\mu \mathrm{I})\end{array}$ & $\begin{array}{l}0.19 \\
(\mu \mathrm{I})\end{array}$ & $\begin{array}{l}0.09 \\
(\mu \mathrm{I})\end{array}$ & $\begin{array}{l}0.04 \\
(\mu \mathrm{I})\end{array}$ \\
\hline MTUM02 & - & - & - & - & + & + & + & + & + & + & + & + \\
\hline MTUM03 & - & - & - & - & - & - & - & + & + & + & + & + \\
\hline MTUM05 & - & - & - & - & + & + & + & + & + & + & + & + \\
\hline MTUM06 & - & - & - & + & + & + & + & + & + & + & + & + \\
\hline MTUM07 & - & - & - & - & - & + & + & + & + & + & + & + \\
\hline MTUM09 & - & - & - & - & - & - & + & + & + & + & + & + \\
\hline
\end{tabular}




\begin{tabular}{|c|c|c|c|c|c|c|c|c|c|c|c|c|}
\hline \multirow[t]{2}{*}{$\begin{array}{l}\text { Test } \\
\text { microorganism }\end{array}$} & \multicolumn{12}{|c|}{$\begin{array}{c}\text { Plant Extract (Ethanol) } \\
\text { Concentration }(500 \mathrm{mg} / \mathrm{ml})\end{array}$} \\
\hline & $\begin{array}{l}100 \\
(\mu \mathrm{l}) \\
\end{array}$ & $\begin{array}{l}50 \\
(\mu \mathrm{I}) \\
\end{array}$ & $\begin{array}{l}25 \\
(\mu \mathrm{I}) \\
\end{array}$ & $\begin{array}{l}12.5 \\
(\mu \mathrm{I}) \\
\end{array}$ & $\begin{array}{l}6.25 \\
(\mu \mathrm{I}) \\
\end{array}$ & $\begin{array}{l}3.12 \\
(\mu \mathrm{I})\end{array}$ & $\begin{array}{l}1.56 \\
(\mu \mathrm{I})\end{array}$ & $\begin{array}{l}0.78 \\
(\mu \mathrm{I})\end{array}$ & $\begin{array}{l}0.39 \\
(\mu \mathrm{I})\end{array}$ & $\begin{array}{l}0.19 \\
(\mu \mathrm{I})\end{array}$ & $\begin{array}{l}0.09 \\
(\mu \mathrm{I})\end{array}$ & $\begin{array}{l}0.04 \\
(\mu \mathrm{I})\end{array}$ \\
\hline MTUM02 & - & - & - & + & + & + & + & + & + & + & + & + \\
\hline MTUM03 & - & - & + & + & + & + & + & + & + & + & + & + \\
\hline MTUM05 & - & - & - & + & + & + & + & + & + & + & + & + \\
\hline MTUM06 & - & - & + & + & + & + & + & + & + & + & + & + \\
\hline MTUM07 & - & - & - & + & + & + & + & + & + & + & + & + \\
\hline MTUM09 & - & - & + & + & + & + & + & + & + & + & + & + \\
\hline
\end{tabular}

Table 6. MIC of different strains of Chloroform extract of Tribulus terrestris by broth dilution method

\begin{tabular}{|c|c|c|c|c|c|c|c|c|c|c|c|c|}
\hline \multirow[t]{2}{*}{$\begin{array}{l}\text { Test } \\
\text { microorganism }\end{array}$} & \multicolumn{12}{|c|}{$\begin{array}{l}\text { Plant Extract (Chloroform) } \\
\text { Concentration (500mg/ml) }\end{array}$} \\
\hline & $\begin{array}{l}100 \\
(\mu \mathrm{l})\end{array}$ & $\begin{array}{l}50 \\
(\mu \mathrm{I})\end{array}$ & $\begin{array}{l}25 \\
(\mu \mathrm{I})\end{array}$ & $\begin{array}{l}12.5 \\
(\mu \mathrm{I})\end{array}$ & $\begin{array}{l}6.25 \\
(\mu \mathrm{I})\end{array}$ & $\begin{array}{l}3.12 \\
(\mu \mathrm{I})\end{array}$ & $\begin{array}{l}1.56 \\
(\mu \mathrm{I})\end{array}$ & $\begin{array}{l}0.78 \\
(\mu \mathrm{I})\end{array}$ & $\begin{array}{l}0.39 \\
(\mu \mathrm{I})\end{array}$ & $\begin{array}{l}0.19 \\
(\mu \mathrm{I})\end{array}$ & $\begin{array}{l}0.09 \\
(\mu \mathrm{I})\end{array}$ & $\begin{array}{l}0.04 \\
(\mu \mathrm{I})\end{array}$ \\
\hline MTUM02 & - & - & + & + & + & + & + & + & + & + & + & + \\
\hline MTUM03 & - & - & + & + & + & + & + & + & + & + & + & + \\
\hline MTUM05 & - & - & + & + & + & + & + & + & + & + & + & + \\
\hline MTUM06 & - & + & + & + & + & + & + & + & + & + & + & + \\
\hline MTUM07 & - & - & - & + & + & + & + & + & + & + & + & + \\
\hline MTUM09 & - & - & - & - & + & + & + & + & + & + & + & + \\
\hline
\end{tabular}

bacterial pathogens demonstrated high resistance to Ampicillin (78\%), Amoxicillin (66\%), and Cotrimoxazole $(78 \%)$, in contrast to the high sensitivity pattern observed with Ofloxacin 83\%, Norfloxacin 71\%, Ciprofloxacin 78\%, Erythromycin 72\%, Chloramphenicol $62 \%$, Gentamicin 58\% and Ceftazidime 60\%. But in this present study demonstrates that all Staphylococcus aureus isolated from pus samples of infectious patients. The high resistance was observed in Ciprofloxacin (60\%), Amoxicillin (50\%) in contrast to high sensitivity pattern observed with Chloramphenicol (30\%), Gentamicin (30\%), Norfloxacin (40\%).

Jain et al. (2014) states that in their study all Staphylococci were susceptible to Vancomycin and Teicoplanin.

\begin{tabular}{|c|c|c|c|c|c|c|c|c|c|c|c|c|}
\hline \multirow[t]{2}{*}{$\begin{array}{l}\text { Test } \\
\text { Microorganim }\end{array}$} & \multicolumn{12}{|c|}{$\begin{array}{c}\text { Plant Extract (Acetone) } \\
\text { Concentration }(500 \mathrm{mg} / \mathrm{ml})\end{array}$} \\
\hline & $\begin{array}{l}100 \\
(\mu l)\end{array}$ & $\begin{array}{l}50 \\
(\mu \mathrm{I})\end{array}$ & $\begin{array}{l}25 \\
(\mu \mathrm{I})\end{array}$ & $\begin{array}{l}12.5 \\
(\mu \mathrm{I})\end{array}$ & $\begin{array}{l}6.25 \\
(\mu \mathrm{I})\end{array}$ & $\begin{array}{l}3.12 \\
(\mu \mathrm{I})\end{array}$ & $\begin{array}{l}1.56 \\
(\mu \mathrm{I})\end{array}$ & $\begin{array}{l}0.78 \\
(\mu \mathrm{I})\end{array}$ & $\begin{array}{l}0.39 \\
(\mu \mathrm{I})\end{array}$ & $\begin{array}{l}0.19 \\
(\mu \mathrm{I})\end{array}$ & $\begin{array}{l}0.09 \\
(\mu \mathrm{I})\end{array}$ & $\begin{array}{l}0.04 \\
(\mu \mathrm{I})\end{array}$ \\
\hline MTUM02 & - & - & - & - & - & + & + & + & + & + & + & + \\
\hline MTUM03 & - & - & - & - & + & + & + & + & + & + & + & + \\
\hline MTUM05 & - & - & - & - & - & - & - & - & + & + & + & + \\
\hline MTUM06 & - & - & - & - & - & + & + & + & + & + & + & + \\
\hline MTUM07 & - & - & - & - & + & + & + & + & + & + & + & + \\
\hline MTUM09 & - & - & - & - & - & + & + & + & + & + & + & + \\
\hline
\end{tabular}


In contrast, the Vancomycin remains the first choice of treatment for MRSA and to preserve its value, its use should be limited to those cases where there are clear indications. But in this present study dissimilar results were obtained by predominant pathogen Staphylococcus aureus indicates resistant to Vancomycin, it proofs that the emerging of drug resistant ability of Staph to be currently initiated.

The result of this present study indicated that bacterial isolates demonstrated high sensitivity to Chloramphenicol being about 70\% sensitive, whereas resistant to $\beta$-lactam antibiotic namely Penicillin $(100 \%)$ was very high. These results are contrary to that obtained for anaerobes isolated from oro-facial infections in earlier study which reported good activities of the later agents against the anaerobes (Nicholes, 2004).

Recurrently, the medicinal plants are the oldest form of healthcare known to mankind. From the ancient time people are using different herbs or plants as the remedy for various diseases. But now a day's people have become dependent on synthetic medicines which have many side effects. So to reduce the side effects we can use medicinal plants for the treatment of common diseases rather than using drugs.

Phan et al. (2001) find out the secondary metabolites are synthesized by the plant as part of the defence system of the plant. The plant contains chebulinc acid, tannic acid, gallic acid, resin, anthroquinone and sennoside. It also contains glycosides, sugar, terpenoids, steroids, phosphoric acid and these compounds were proven to exhibit antibacterial, antifungal, antiviral and anticarcinogenic (Neamsuvan et al., 2012). Hence, the present study to logically select a leaf part of bio-medically active Tribulus plant to exhibit a broad antimicrobial activity against wound pathogen Staphylococcus aureus.

Ali et al., (2001) confirmed that their study the Tribulus terrestris had no detectable antibacterial activity against any of the infectious disease causing reference bacteria. For this reason, in this present study choose a plant material of Tribulus to check the vital activity against infectious disease that proved the Indian leaf of $T$. terrestris were active against clinically dominant pathogen S.aureus isolated from post-operative wound infection.

Recurrently, the plant extract is highly sensitive when compared to the standard antibiotic. These data indicate that Gram-positive bacteria are the most sensitive strains for the different extracts, which exhibited their main antibacterial activity on Gram-negative bacteria (Bakri and Douglas 2005). Our results are in good agreement with previous works (Al Maofari et al., 2013) showing a weaker activity of essential oil of Anis and Salvia tomentosa and also Nair and Chanda, a (2008) also reported Gram positive were more sensitive. Ethanol extract showed more effect than aqueous extract in inhibiting the growth of the bacterial strains (Nair and Chanda, b 2007; Firas et al., 2008). The growth of the Gram positive strains was found more inhibition than Gram negative. In this present study, similar results was observed the antimicrobial activity of 7 different solvent plant extract was tested against S.aureus. The maximum antibacterial activity was seen in Ethyl acetate extract (100 $\mathrm{pl}$ ) of Tribulus terrestris. Intermediate antibacterial

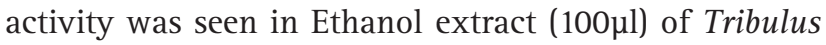
terrestris (Fig. 3).

\section{CONCLUSION}

The present study revealed that the post operative wound infection is one of the most common chronic infectious diseases of human is also a serious problem among wound of post-operative patients caused by predominant pathogen Staphylococcus aureus. Therefore, effective treatment and management of wound infections in hospital and community setting will require detailed knowledge of the infecting bacterial pathogens and their antibiogram peculiar to the environment for drug selection. Resistant bacteria which are human pathogens may cause the disease, they may still be dangerous because they can transfer their antibiotic resistance genes to other organism. Antimicrobial resistances of bacterial pathogens are a major problem for the treatment of animal and human patients with bacterial diseases. There is an alarming increase of infections caused by antibiotic resistant bacteria to urgently need of antimicrobial compound to treat a pathogenic organism. Recurrently the plants have been one of the important sources of medicine since the beginning of human civilization. There is a growing demand for plant based medicines to activity against several infectious pathogens. Hence the current study concluded that the different solvent extract of Tribulus plant has different mode of action to eradicate the wound pathogen around the surgical site. The plant extracts can also be exploited in designing the wound care products.

\section{REFERENCES}

Al Maofari A, S. EL Hajjaji, A. Debbab, S.Zaydoun, B. Ouaki, R. Charof, Z. Mennane, Hakiki A and Mosaddak M (2013). Chemical composition and antibacterial properties of essential oils of Pimpinella anisum L. growing in morocco and yemen. Scientific Study \& Research Chemistry \& Chemical Engineering, Biotechnology, Food Industry. Vol. 14, Issuev1, 011 - 016.

Al-Bayati F.A, and Al-Mola H.F. (2008) Antibacterial and antifungal activities of different parts of Tribulus terrestris growing in Iraq. J. Zhej.Univ Sci. Vol. 9, Issue 2, 154- 159.

Anaya D.A and Dellinger E.P (2006). Challenges in the prevention of surgical site infections. Infections in Medicine. Vol 23, Issue 3, 120-126. 
Awadh-Ali NA, W.D. Julich, Kusnick C and Lindequist U (2001). Screening of Yemeni medicinal plants for antibacterial and cytotoxic activities. J Ethno pharmacol. Vol. 74, Issue 2, 173-179.

Ayliffe G.A.J, A.P. Fraise, Geddes A.M. and Mitchell K (2000). Control of Hospital Infection: A Practical Handbook; 4th edn. London: Arnold.

Bakri IM and Douglas CWI (2005). Inhibitory effect of garlic extract on oral bacteria. Arch Oral Biol. Vol. 50, 645-651.

Bourke CA, G.R Stevens, et al. (1992). Locomotor effects in sheep of alkaloids identified in Australian Tribulus terrestris. Aust. Vet. J. Vol. 69, 163-165.

Church D, S. Elsayed, O. Reid, Winston B and Lindsay R (2006). Burn Wound Infections. Clin. Microbiol. Rev. Vol. 19, Issue 2, 403-434.

Ergin C and Mutlu G (1999). Clinical Distribution and Antibiotic Resistance of Pseudomonas species. Eastern J. Med. Vol. 4, Issue 2, 65-69.

Firas A, Al-Bayati and Hassan F. Al-Mola (2008). Antibacterial and antifungal activities of different parts of Tribulus terrestris L. growing in Iraq. J. Zhejiang. Univ. Sci., B. Vol. 9, Issue 2, 154-159.

Jain A., S. Bhatawadekar and M. Modak (2014). Bacteriological profile of surgical site infection from a tertiary care hospital, from western India. Indian Journal of Applied Research. Vol. 4, Issue (1), 397-400.

Lewis K and Ausubel F.M (2006). Prospects for plant-derived anti-bacterials. Nat. Biotechnol. Vol. 24, Issue 12, 1504-1507.

Mohammed B., Yasidi H, Denue Ballah Akawu (2015). Retrospective analysis of bacterial pathogens isolated from wound infections at a Tertiary Hospital in Nguru, Yobe State Nigeria . American Journal of Biomedical and Life Sciences. Vol. 3, Issue 1, 1-6.

Nair, Ratish and Chanda Sumitra, V. (2007a). Antibacterial activities of some medicinal plants of the Western Region of India. Turk. J. Bot. Vol. 31, 231-236.

Nair, Ratish and Chanda Sumitra, V. (2007b). In vitro antimicrobial activiy of Psidium guajava leaf extracts against clinically important pathogenic microbial strains. Braz. J. Microbiol. Vol. 38, 452-458.

Nascimento G.G.F, J. Locatelli, Freitas P.C and Silva G.L (2000). Antibacterial activity of plant extracts and phytochemicals on anbiotic resistant bacteria. Braz. J. Microbiol. Vol. 31, 247-256.
Naz R, Hafsa Ayub, Sajid Nawaz , Zia U Islam , Tayyaba Yasmin, Asghari Bano, Abdul Wakee, Saqib Zia and Thomas H Roberts (2017). Antimicrobial activity, toxicity and anti inflammatory potential of methanolic extracts of four ethno medicinal plant species from Punjab, Pakistan. BMC Complementary and Alternative Medicine. Vol. 17, Issue 302, 1-13.

Neamsuvan 0, P. Singdam, Yingcharoen K and Sengnon N (2012). A survey of medicinal plants in mangrove and beach forests from sating Phra Peninsula, Songkhla Province, Thailand. J. Med. Plants Res. Vol. 6, Issue (12), 2421-2437.

Nichols RL, (2004). Current Strategies for Prevention of Surgical Site Infections. Curr Infect Dis Rep. Vol. 6, Issue 6, 426-434.

Percevil S and Bowler P (2004). Understanding the effects of bacterial communities and biofilms on wound healing. Available from: URL: ttp://www.worldwidewounds.com

Phan TT, L. Wang, P. See, R.J. Grayer, Chan SY and Lee ST (2001). Phenolic compounds of Chromolaena odorata protect cultured skin cells from oxidative damage: implication for cutaneous wound healing. Biol. Pharm. Bull. Vol. 24, Issue 12, 1373-1379.

Reichman DE and Greenberg JA (2009). Reducing Surgical Site Infections: A Review. Rev Obstet Gynecol. Vol. 2, 212-221.

Sengul M, H. Yildiz, et al. (2009). Total phenolic content, antioxidant and antimicrobial activities of some medicinal plants. Pak. J. Pharm. Sci. Vol. 22, Issue 1, 102-106.

Sibanda T and Okoh A.I (2007). The Challenges of overcoming antibiotic resistance: plant extracts as potential sources of antimicrobial and resistance modifying agents. Afr. J. Biotechnol. Vol. 6, Issue 25, 2886-2896.

Sudharameshwari K and Radhika J (2007). Antibacterial Screening of Aegle marmelos, Lawsonia inermis and Albizzia libbeck. AJTCAM. Vol. 4, Issue 2, 199-204.

Suljagic V, M. Jevtic, Djordjevic B and Jovelic A (2010). Surgical site infections in a tertiary health care center: Prospective cohort study. Surg Today. Vol. 40, 763-71.

Tahir MS, (1995). Surgical wounds and prevention of infection in the hospital. The Professional. Vol. 2, 173-81.

Tredget E. E, H. A. Shankowsky, R. Rennie, Burrell R. E and Logsetty S (2004). Pseudomonas infections in the thermally injured patient. Burns, Vol. 30, 3-26.

Wang B., Ma L and Liu T (1990) 406 cases of angina pectoris in coronary heart disease treated with saponin of Tribulus terrestris. Chung Hsi. J. Chieh Ho Tsa Chih. Vol. 10, Issue 2, 85-87 (in Chinese). 